DOI 10.26886/2524-101X.8.1.2022.2 $\begin{array}{r}\text { ISSN 2524-101X } \\ \text { eISSN 2617-541X }\end{array}$

\title{
Review of the Positions of the Ukrainian Supreme Court on Maritime Law Disputes (Administrative Jurisdiction)
}

\section{Albert Yezerov*}

Yezerov. A. (2022). Review of the Positions of the Ukrainian Supreme Court on Maritime Law Disputes (Administrative Jurisdiction). Lex Portus, 8(1), 28-48. https://doi.org/10.26886/2524-101X.8.1.2022.2

*PhD in Law, Associate Professor, judge of the Supreme Court (8, P. Orlyka St., Kyiv, Ukraine) https://orcid.org/0000-0003-3294-1553

(c) 10 This work is licensed under a Creative Commons Attribution-

\section{ABSTRACT}

The present paper provides an overview of the legal positions of the Ukrainian Supreme Court on maritime disputes within the framework of administrative jurisdiction. In this class of cases, disputes arise about the performance or non-performance of public administration functions or the provision or nonprovision of administrative services in matters related to navigation, fisheries, seaports functioning, environmental protection in the coastal waters, etc. Mainly, this paper focuses on the cases concerning prohibitions for ships to call out from a port, services provided by harbormasters, pollution of coastal waters, and fishing. In addition, special attention is paid to disputes related to the legal regime of seaports enforcement in terms of the performance of 
functions of port authorities and other agencies entitled to various types of controls in the port (in particular, environmental).

The keywords: maritime disputes, administrative jurisdiction, seaports, harbormasters, port authorities, Ukraine.

\section{Introduction}

The practice of court decisions on disputes related to merchant shipping in Ukraine mainly refers to the jurisdiction of commercial courts. However, cases, the subject of which is appeal of decisions and actions of governmental authority, belong to the jurisdiction of administrative courts. In several categories of such cases, The Supreme Court has formulated legal positions, which are binding on regional and appeal courts in resolving similar disputes. A brief overview of the relevant legal positions is offered. Most cases are decided by the courts of the first instance and do not go for review on appeal and cassation. Such situation derives from the fact that most cases need to be resolved as soon as possible due to the threat of financial losses for shipowners. Since 2018, the Supreme Court has ruled out on 14 administrative cases related to the settlement of maritime disputes. These cases concerned the powers of the port captain, activities within the internal sea waters and territorial sea of Ukraine (including in the field of environmental safety of sea waters and territorial sea from pollution and littering), the legal regime in seaports, preservation of state property of ports and compliance with customs rules in ports.

\section{Disputes concerning the authorities of the harbor master}

In case No. 814/1100/18 on granting permission for the vessel to enter commercial seaport the Company appealed to the court the inaction of Port Authority in granting permission or refusal to enter the port, and non-agreement and failure to notify the plaintiff and the Master of vessel (agent) about the conditions of pilotage in the port, mooring berth or place of anchorage and scheduled date of mooring. The lawsuit was justified by the fact that due to the 
inaction of the defendants there was a disruption of the schedule of the Company's terminal in relation to cargo turnover and fulfilment of obligations of Ukrainian and foreign partners.

The courts of first instance and appeal court dismissed the lawsuit.

Appeal court was guided by the fact that the legal relationship between the Company and the port branch are civil regarding the provision of the latter services for the use of berths and berth infrastructure in accordance with the purpose of the easement and the terms of the easement Agreement. At these legal relations, the actions or inaction of the Port officials relate exclusively to the subjects defined within this competence. Instead, the Company is not included in the circle of persons to whom this legal relationship applies, so there is no violation of its rights or interests in the field of public relations.

The Supreme Court closed the case and clarified that the dispute should be resolved according to commercial litigation proceedings, as the legal relationship between the plaintiff, another company (which provides ship's agency services) and the Port. It is a relationship between commercial entities regarding the provision the latest services to vessels on the approaches and directly in the seaport water area for their safe navigation, maneuvering and berthing. For these services, the company (which provides ship`s agency services) paid to the Port.

The Supreme Court concluded that in legal relationships in dispute the defendants do not perform administrative functions in relation to the plaintiff. The relationships between the plaintiff and the Port branch are civil regarding the provision of services for the use of berths and berth infrastructure for the purpose of easement.

Thus, the claims in the case were stated in order to restore the violated civil (property) right, and the dispute in this case is of a private law nature, which makes it impossible to resolve dispute in administrative proceedings. 
In the case No. 2140/1776/18 on the refusal of the vessel to leave the port due to the prohibition decision of the border service the company appealed to the court against the actions of the Harbor master regarding to issue instructions and inaction of the Harbor master regarding issue a permit for the vessel to leave the Kherson Sea Port, as well as the decision of the Azov-Black Sea Regional Department of the State Border Guard Service of Ukraine.

In support of claims, the plaintiff referred to the fact that he had been the shipowner of this vessel since 2011 on the basis of a leasing agreement. The actual transfer of the vessel took place on 04.08.2011, and on 20.08.2018 the plaintiff transferred ownership of the vessel in a manner and in terms agreed by the leasing agreement. From 20.08.2018 the plaintiff is the registered owner of the vessel. The Harbormaster instructions are based on the circumstances of the application of sanctions against to the leasing company for a period of 3 years. In this case, the defendants unlawfully ignore the plaintiff's ownership of the vessel in the absence of any legal restrictions and violations by the plaintiff, acting in excess of authority.

The courts of first instance and appeal court dismissed the lawsuit on the grounds that the Harbormaster and the Border Guard Service had acted within the requirements of the law in adopting the appealed decisions and instructions.

The Supreme Court upheld the judgments of the courts of previous instances, based on the following. Decisions regarding the application, reversal and amendment of sanctions are made by the National Security and Defense Council of Ukraine and put into effect by the Decree of the President of Ukraine. Relevant decision shall enter into force upon the issuance of the Decree of the President of Ukraine and shall be binding to perform.

The State Border Guard Service is the body authorized to grant a permission to cross the border, to inspect the crew members regarding compliance with the law when crossing the border. 
The Border Guard Service, in deciding to prohibit the vessel from leaving the port, acted within its powers and in accordance with applicable law.

The court noted that according to the certificate of registration of the vessel in the international register of vessels, the plaintiff became the owner of the vessel only on 20.08.2018, the vessel as an asset of the leasing company was blocked on 10.08.2018.

Therefore, at the time of entering the port of the vessel, the plaintiff was not its owner, and the transfer of ownership to the plaintiff is not a circumstance that may be ground for changing or lifting the sanctions applied to the assets of the leasing company.

In the case of No. 640/1151/19 on appealing the provisions about the Harbormaster and the service of the Harbormaster Marine Transport Workers' Trade Union of the Chornomorsk Sea Port appealed to the court paragraph 33 of the order approving the Amendments to certain orders of the Ministry of Transport of Ukraine, the Ministry of Transport and Communications of Ukraine and the Ministry of Infrastructure of Ukraine, arguing that moot point about reassignment of the service of the Harbormaster from the seaport administration to the State service of sea and river transport does not comply with the provisions of the law, according to which the organization and safety of navigation in the seaport is the competence of the Harbormaster and is the responsibility of the seaport administration of Ukraine.

The courts of first instance and appeal court dismissed the lawsuit, arguing that by amending the Regulations on the Harbormaster and the Harbormaster Authority, the defendant acted within his powers in accordance with the law.

The Supreme Court affirmed the decisions of the courts of previous instances, arguing that the functions of the Harbormaster are to supervise (control) the safety of navigation in a seaport, on approaches to it and in adjacent water areas. At the same time, 
ensuring the safety of navigation is entrusted to the administration of the seaports of Ukraine.

The Supreme Court noted that the legislation separates the concept of "state supervision over safety of navigation in the seaport", which is carried out by the Harbormaster, "ensuring safety of navigation in the seaport", which is entrusted to the Ukrainian Sea Ports Authority, as well as "performing of state politics in the field of safety in maritime and river transport", which relates to the competence of the Maritime Administration.

The organization and ensuring safety of navigation is carried out by the state enterprise "Ukrainian Sea Ports Authority", whose employees are not civil servants, so they are not authorized to perform state functions, i.e. the functions of state supervision and control. State supervision and control are provided by the central executive body, which ensures the implementation of state policy in the field of safety in maritime and river transport - the Maritime Administration.

The disputable order established the division of functions between the State Enterprise "Ukrainian Sea Ports Authority" and the Maritime Administration in terms of providing administrative services and ensuring safety of navigation and included the service of the Harbormaster in the Maritime Administration. This resulted in the appointment Harbormaster as civil servants by the Maritime Administration.

In case No. 815/2294/15 on recognition of illegal inaction of Harbormaster to issue a permit for the vessel to leave the seaport the company appealed to the court the inaction of the Harbour master to issue a permit for the vessel to leave the Illichivsk Commercial Seaport. The lawsuit is based on the fact that the Harbormaster was inactive, not responding to the master request to leave the port, and ignoring the letter of protest, which he declared the same day. 
The court of first instance dismissed the lawsuit, citing the fact that there is no evidence of submission to the Harbormaster of all documents established under the law and required to obtain a permit for the vessel to leave the Illichivsk seaport.

The appeal court, with which the Supreme Administrative Court of Ukraine agreed, cancelled the judgement of the court of the first instance and hold a new one on the satisfaction of the claim, which is due to the fact that Harbormaster did not prove the fact of the adoption of the relevant order to refuse issuance a permit for the vessel to leave the port or to grant such permission, as well as the conduct of any correspondence (during the relevant period) using the forms of the Harbormaster regarding a controversial issue or the issuance of another act falling under the definition of a legal act of individual action and could be appealed in a judicial and/or administrative order to the Chairman of the Ukrmorrichinspektsii.

The Supreme Court refused to satisfy the application for review of the judgement of the Court of cassation instance on the grounds of unequal practice of use by this Court the Article 91 of Merchant Shipping Code of Ukraine in similar legal relations in view of the lack of both law enforcement opinion and objective possibility to compare circumstances in another case due to incomplete circumstances established in this case, essential for the proper resolution of the dispute.

\section{In the case No. 815/505/16 about the appeal of the Harbormaster} failure of obligation to refuse to issue a permit to leave the port of the vessel the plaintiff appealed to the court against the actions of the chief of port supervision of the port branch, related to the granting of permission to leave the port with a number of passengers on board in excess of 12 person.

The lawsuit is based on the fact that plaintiff was transporting a lorry on a ferry, the driver of which he was. There were more than 
12 passengers on board. Regarding the information that the ship is a cargo one, the plaintiff believes that the Harbormaster of the Illichivsk seaport was not entitled to issue a permit to leave the sea ferry port, as one that does not have the appropriate ship documents to prove the right to carry more than 12 passengers, in particular, Passenger Ship Safety Certificate.

The court of first instance partially satisfied claims, in particular, declared illegal actions of the senior harbormaster supervision to issue a permit for the vessel to leave the seaport, the flag - the Republic of Bulgaria, from the port with the number of passengers on board exceeding 12 (twelve) persons.

The court of first instance took into account the violation of the procedure for issuing a permit for the vessel to leave the seaport, as it did not contain information about the date and time of departure from the port, as well as the person with the position and name of the signatory. In addition, the court noted that the senior harbormaster exceeded his authority and did not take into account the circumstances of having more than 12 passengers on board, which require obligation of receiving Passenger Ship Safety Certificate.

The judgement of the Appeal court affirmed the decision of the court of first instance and adopted a new judgement, which rejected the lawsuit, motivated by the fact that the Harbormaster had the right to issue a permit for the vessel to leave the seaport with more than 12 passengers on board without presenting Passenger Ship Safety Certificate.

The Supreme Court agreed with the appeal court's reports, citing an analysis of the provisions of the 1974 International Convention for the Safety of Life at Sea (SOLAS 74 Convention) and the 1974 Athens Convention relating to the Carriage of Passengers and their Luggage by Sea.

On the basis of international rules, the Court concluded that drivers of lorries on a sea ferry, who did not perform any duties related to the activities of this vessel, belong to the category of passengers. 
Tin this case the ferry is not a special purpose vessel within the meaning of the 2008 Code of safety for special purpose ships. Therefore, drivers of lorries which are transferred by the ferries cannot be classified as special staff.

Regarding the fact that there were 17 passengers on the ferry drivers of cargo and passenger vehicles, i.e. more than 12 people, the master according to the SOLAS 74 Convention had to present Passenger Ship Safety Certificate.

However, the SOLAS 74 Convention provides that if the Administration (government of the State under the flag of which the vessel has the right to sail) considers that the protected nature and conditions of the voyage are deemed inappropriate or excessive to comply with any specific requirements of this chapter, it may exempt certain vessels or categories of vessels which are not more than 20 miles from the nearest shore during the voyage.

In this case it was established that on 13.02.2014 the Ministry of Transport, Information Technology and Communications under the authority of the Government of the Republic of Bulgaria and the Maritime Administration of Bulgaria issued a certificate of release of the vessel, port of registration Varna, from the requirements for lifeboats and float boats SOLAS 74. Moreover, according to the licenses drivers are considered to be individuals who perform any duties related to the activities of that vessel on board.

Ukraine, as a member of an International Maritime Organization, must comply with the rules and regulations that are in the effect in the organization, and therefore the senior harbormaster, who issues a permit for the vessel to leave the seaport, the flag of the Republic of Bulgaria, from the Illichivsk seaport, could not and did not have the authority to assess legitimacy of exemption certificate issuance.

The State Inspectorate of Ukraine for Maritime and River Transport Safety (Ukrmorrichinspektsiya) has issued a report on the possibility of recognizing the of exemption certificates issued by the Maritime Administration of the Republic of Bulgaria to ferries 
"Heroes of Odessa" and "Heroes of Sevastopol" which are sailing under the Bulgarian flag, in the part of presence of technical staff drivers of lorries on board who are not passengers, but are persons who work or perform duties related to the activities of this vessel.

Thus, the harbormaster had the right to issue a permit for the vessel to leave the seaport, the flag of the Republic of Bulgaria with the number of passengers on board, exceeding 12 people without presenting him Passenger Ship Safety Certificate.

\section{Disputes concerning activities within the inland sea waters} and the territorial sea of Ukraine

In the case No. 420/4129/19 on pollution of inland sea waters and territorial sea of Ukraine due to discharge of ballast waters into the water area of the Adzhalyk Liman the plaintiff appealed to the court against the actions of the State Ecological Inspection of the North-Western District of Black Sea Region with a claim, and also applied the court for compensation for losses, inflation losses and $3 \%$ per annum.

In support of the claims, the plaintiff pointed out that the basis for payment of the claim was to bring the master of the vessel to administrative responsibility for alleged pollution of inland waters due to discharge of contaminated water from the uninsulated ballast system in excess of maximum permissible concentrations of pollutants that was recorded into report and decision. The claim was paid in order to prevent the ship from idle in the port of "Yuzhny". At the same time, the plaintiff believes that the payment of the claim did not have proper legal and factual grounds, and therefore the amount of the claim was collected illegally and is refundable in full.

The Court of the first instance and the Appeal court rejected the lawsuit, based on the fact that the Inspection is authorized to file claims for damages and losses caused to the state as a result of breach of legislation on matters within its competence, and calculate their amount. The fact of pollution was established by sampling and 
laboratory tests carried out by the ecological inspection within its powers.

The District Administrative Court concluded that the defendant's actions in bringing the claim did not directly engender legal consequences for the plaintiff.

The Supreme Court disagreed with the courts' decisions, annulated them and remanded the case for new trial, drawing the following conclusions.

The legal method for recovering damages caused to the environment stipulates that in case of rejection of the claim, the bodies of the State Ecological Inspection of Ukraine apply to the court with a relevant claim to the owner of the vessel for damages. In considering the case on such a claim, the court checks, in particular, whether the offense was committed, whether damages were caused and what amount of damages. The court procedure for recovery of damages allows a commercial entity to protect itself from unreasonable claims.

At the stage of filing a claim, the addressee of the claim does not have any restrictions or obstacles in carrying out normal commercial activity.

However, in the situation of the plaintiff, which is typical for the ports of Ukraine due to the presence of legislative gaps, this method does not work. Prohibition for a vessel to leave a port due to nonpayment of the amount of damages forces a shipowner to pay an amount of the claim. After payment of the amount specified in the claim, the Inspection the need to go to court is eliminated. De jure, the Inspection exercised its powers in full: found breaches, recorded, filed a claim, recovered damages.

Usually, the voluntary payment of the claim amount indicates an agreement with the claim. The shipowner could reject a claim if he considered it unjustified. However, the claim in this case resulted in prohibition for the vessel to leave the port. And this, in its turn, leads to losses from downtime and a number of other negative consequences. Therefore, the payment of the claim amount in such 
forced circumstances for the plaintiff cannot be called voluntary or such that certifies agreement with the claim.

Considering these factors, the shipowner paid the amount of the claim as pledge (guarantee). Such behavior has rational reasons and protects the interests not only of the shipowner, but also of the state, to which a claim for damages may be subsequently filed due to the illegal detention of the vessel.

If we assess the context of this case, the payment of the amount of the claim does not indicate the agreement with the claim. The dispute concerning the existence of the offense for which the claim is filed remains. The shipowner continues to believe that his rights have been injured.

The remand of the case for new trial is justified by the fact that the courts limited themselves to assessing the possibility of appealing the actions concerning the claims, and did not examine the grounds and procedure for verification, did not assess the evidence justifying the damage. Therefore, the courts did not examine the evidence in this part of the case, did not resolve the dispute.

The court provided a number of instructions that must be taken into account by the court of first instance in a new trial.

In the case No. 808/2192/16 on the appeal of the refusal to agree on the research program concerning fishing in the fivekilometer coastal zone along the Ukrainian coast of the Azov Sea the private company appealed to the court against the refusal of the State Fisheries Agency to agree on a research program to study the possibility of fishing gobies fish in a five-kilometer coastal zone along the Ukrainian coast of the Azov Sea from the Kerch Strait to the edge of the Belosarai Spit during the calendar year with establishing the terms of prohibition of its acquisition.

The lawsuit is based on the fact that in the five-kilometer coastal zone of the Azov Sea, each of the parties (both Ukraine and the Russian Federation independently) takes measures to regulate 
fishing for biological resources for which the Commission does not set fishing capture levels (limits) and during its implementation the damage cannot be caused to the reserves of these species, and outside the five-kilometer coastal zone of the Azov Sea the regulation is performed by decisions of the Commission. Therefore, since the Commission agreed on the independent regulation of each of the Parties to the fishery in the five-kilometer zone of the Azov Sea and the Commission did not set capture levels (limits) of gobies fish in the five-kilometer coastal zone of the Azov Sea, the plaintiff's research program wasn't subject to consideration by the Commission with applying of the decision to provide scientific research on this program. The plaintiff considers that there isn 't non-compliance with procedures in taking decision concerning conducting such research and agreement of program in State Fisheries Agency.

The Court of first instance and the Appeal court affirmed the claim, justifying that all research and industrial work aimed at improving the rules of fisheries in the Azov Sea Basin, could be carried out only by decision of the Commission, in its turn research proposed by the plaintiff in the program which is aimed at studying the possibility of changing the Rules of Fisheries in the Azov Sea Basin was not considered and agreed within the work of the Commission, so the defendant rightly refused to approve the program with the plaintiff. At the same time, Clause 7.2.8 of the Protocol of the XXVII Session of the Commission of 27-29.10.2015 in Sochi (Russian Federation) shouldn't be applied to the legal relationships in dispute, as Clause 1.2 of the Regulation does not contain any exceptions, sub-clause "g" of clause 7.2.1 of abovementioned Protocol of Commission regulates industrial confiscation of gobies fish in the Azov Sea during current year.

The Supreme Court agreed with the courts of previous instances and justified its judgement by the fact that international agreements that have been ratified and entered into force define the right of the Commission, in particular, to coordinate industrial fisheries, conduct 
research connected with capture of biological resources in Azov Sea in the area of the validity of the Agreement.

The research defined by the Program is aimed at identification of the possibilities of industrial fishing in the five-kilometer coastal zone along the Ukrainian coast of the Azov Sea to the Kerch Strait. Taking into consideration the ultimate goal of the program, the Court agreed with the conclusions of the courts of first instance that the program is aimed to change fisheries rules and fishing regimes.

The proposed research work was not considered and not agreed upon within the work of the Commission.

\section{Disputes concerning the legal regime in the port area}

In case No. 815/658/18 on the recognition of illegal inaction of the State Ecological Inspection of Ukraine in not carrying out radiological control of the cargo, which led to the detention of the ship the company appealed to the court against the inaction of the State Ecological Inspection of Ukraine for not conducting radiological control of the cargo, which led to the detention of the vessel. The claim is justified by the fact that the officials of the State Ecological Inspection of Ukraine did not conduct a radiological inspection of the vessel in due time and evaded stamping "IMPORT/ EXPORT ALLOWED" or "IMPORT/EXPORT PROHIBITED" on the bills of lading within seven days. The defendant's inaction regarding the failure to conduct radiological control of the cargo resulted in the unreasonable detention of the vessel, breach of rights and interests, as well as damage to the plaintiff's property.

The courts of the first instances and appeal courts satisfied the lawsuit, reasoning that the Inspection, as a subject of authority, failed to prove to the court that the absence of a radiological control of the ship's cargo within the period specified by the law in force was lawful. The courts did not take into consideration the defendant's reference to the existence of breaches of environmental law, radiation safety standards, and rules by the plaintiff, and stated that in such a case the 
defendant should have stamped "Radiological control - IMPORT/ EXPORT PROHIBITED". The Supreme Court dissented with the courts of previous instances, overturned the court decisions, and remand the case for a new trial, motivated by the fact that during the hearing the defendant repeatedly noted that the reason for detaining the object of customs control was the fact of identifying breaches of the legislation. In assessing the defendant's actions, the courts did not provide an evaluation of the actual presence or absence of breaches of legislation by the plaintiff, therefore, the conclusions about the presence of illegal inaction in the actions of the defendant, consisting in breaches of the terms of radiological control and putting the appropriate stamps, under such circumstances, are premature. The courts should take into consideration the appropriateness of the inspector's actions in extending the terms of the control.

In case No. 808/3534/13-a regarding non-compliance with conditions of storage of food products (fish) located in boxes on the berths in the port area private enterprise appealed to the court the order of the Head of Azov Basin Department of the General Administration of State Sanitary Epidemiological Service on Water Transport, Head State Sanitary Doctor of Azov Basin to remove causes and conditions contributing to breaches of sanitary legislation. The lawsuit is based on the fact that the fishing vessel, from permits and other documents, is engaged in the removal of aquatic biological resources (hereinafter the ABR) from the natural environment. Subsequently, the ABR in an unprocessed condition is on board the vessel until its arrival to the port, where the procedure of transshipment from the vessel to rented cars is carried out through the state berths by the efforts of the crew members. As a result of the fact that the port did not allow the crew members to transfer the untreated ABR to the rented cars in time, waste was generated in 37 boxes on board the vessel, since the vessel is not equipped with environmental protection equipment for complete disposal of 
all types of vessel waste. The Port ignored the lawful demands of the fishing vessel, put forward immediately after the formation of waste on board, to provide the berth with garbage containers, which should be delivered by the Port to an enterprise authorized to dispose of this kind of waste in accordance with the procedure established by the Law. The courts of the first instance and appeal courts satisfied the lawsuit, motivating it by the fact that the obligation to maintain the berths and adjacent areas in the appropriate sanitary standard is imposed on the Port, which owns the said berths. The appeal court additionally considered that the defendant had not provided evidence of the plaintiff's inspection. The Supreme Court agreed with the courts of previous instances because the reason for the injunction were acts of sanitary and epidemiological examination of the Port wharf, which were carried out on the basis of orders of the Azov Basin Department of the General Directorate of State Sanitary and Epidemiological Service on Water Transport. The inspections were carried out with the Port officials' participation, without notification and participation of the plaintiff, which is a breach of the current legislation.

In the case of No. 815/6436/15 on establishing the lack of powers of the port authorities to set the rate of the tonnage dues for foreign-flagged vessels engaged in cabotage as for vessels engaged in international voyages the company appealed to the court against the action of the Administration of seaports on the collection of tonnage dues from vessels under a foreign flag engaged in cabotage, at the rates for vessels engaged in international voyages.

The plaintiff stated that the defendant's unreasonable charging of a tonnage due from vessels under a foreign flag engaged in cabotage, at rates for vessels engaged in international voyages, considers the invoices issued by the defendant to be illegal, which resulted in damages in the form of unjustified paid tonnage due which the plaintiff asked to charge with calculating of interests for the use of funds. 
The court of the first instance satisfied the lawsuit partially, justifying the illegality of establishing of the defendant's tariffs for cabotage voyages, depending on the ownership of the vessel, which breaches the principle of equality and discriminates against commercial entities.

The appeal court canceled the judgement of the court of first instance and adopted a new one about the rejection of the lawsuit, arguing that the defendant's actions to charge the tonnage due are lawful.

The Supreme Administrative Court of Ukraine overturned the court decisions and closed the proceedings, regarding that the case should not be considered in administrative proceedings, based on the fact that the defendant does not set port dues, but determines their size using rates approved by the Ministry of Infrastructure of Ukraine. The relationships established between the parties foresee equality of their participants, freedom of their will, absence of any subordination or power influence.

The Supreme Court reviewed the ruling of the Supreme Administrative Court of Ukraine, as a result of which the relevant ruling was overturned and the case was sent to the court of cassation instance for further consideration. This decision is motivated by the fact that the collection and determination of the rate of port dues belong to the administrative functions.

The court concluded that disputes arising from the legal relationship between a private law entity and government entity represented by other entities in the exercise of their power administrative functions under the law belong to the jurisdiction of administrative courts.

Case No. 2a-12088/09/1570 on checking the procedure of applying tariffs for services in seaports. The Port appealed to the court the order of the State Inspection for price control about the application of economic sanctions for breach of state price discipline, adopted in relation to the Port Yuzhny. 
The claims are justified by the fact that the tariffs for payment of services for registration of arrival and departure of vessels in the port state control inspection are not defined by law, when providing other services for shipowners, free prices are applied. It also believes that the tonnage, canal, anchor and berth dues are targeted port dues, so the port cannot use the funds from these dues to cover the cost of services of the port state control inspection for registration of arrival/departure of vessels and maintenance of the inspection is impossible.

The court of the first instance affirmed the claim. The appeal court overturned the judgement of the court of first instance and adopted a new judgement on partial satisfaction of the lawsuit: declared illegal and overturned the order regarding the obligation to review tariffs for heat supply, water supply and sewerage services and bring them in line with the Tariff Procedures, agreed on invoices of planned costs with the State Inspection for Prices in the manner prescribed by order of the Ministry of Economy of Ukraine. The rest of the lawsuit was rejected.

The courts considered that registration of arrival of vessels in the port and departure from it is not a service, in the provision of which "free prices" are applied, as provided in Article 62 of the Fees and Charges. Therefore, the port state control inspection does not have the authority to establish or hold additional fees that are not provided by law.

The Supreme Court overturned the judgments in the part where the lawsuit was affirmed and, in this part, adopted a new decision by which the decision of the State Inspection for Price Control about the application of economic sanctions for violation of state price discipline repealed the application of economic sanctions for breach of state price discipline regarding Port Yuzhny in terms of confiscation of a certain amount from the state budget and the application of penalties. In the other part, the decision of the appeal court was left unchanged. 
The Supreme Court was guided by the fact that registration of arrivals and departures from the port is a legally defined function of the harbormaster, who is an official authorized to exercise state control of navigation in the commercial seaport of Ukraine and is not a service for providing of which free prices are applied.

For each arrival of vessels into the port and departure from the port, the tonnage due is charged in the amount determined by the Regulations on port dues.

The legislation does not provide the establishment by the port of any other fee for registration of vessels ' arrivals in the port and departure from it.

In resolving the claim for reversal of the decision about application of economic sanctions, the panel of judges noted that it is a decision about application of administrative-economic sanctions. The defendant had to decide about the application of this type of sanctions only within six months from the date of detection of the breach, but not later than one year from the date of breach by this entity of the rules of commercial activity.

\section{Conclusions}

An analysis of maritime law and case law in resolving maritime disputes reveals to the legal community several legal issues that update research in this area and the basis for legislative initiatives to improve legal regulation in the field of maritime relations. At the same time, the case law of the Ukrainian Supreme Court eventually shows extensive opportunities to protect the rights and interests of individuals and legal entities from the actions of public authorities in the application of maritime law.

\section{REFERENCES}

Supreme Court. (2018, June 5). Case about the appeal of the Harbormaster failure of obligation to refuse to issue a permit to leave the port of the vessel. (No. 815/505/16). http://iplex.com.ua/ 
doc.php?regnum $=74579990 \&$ red $=100003248 \mathrm{dbb} 748 \mathrm{e} 89690546 \mathrm{e} 43 \mathrm{~d} 0904 \mathrm{f} 7$ ea18\&d=5 [in Ukrainian].

Supreme Court. (2020, August 17). Case on appealing the provisions about the Harbormaster and the service of the Harbormaster. (No. 640/1151/19). https://ips.ligazakon.net/document/view/VS200228?ed=2020_08_17\&an=62 [in Ukrainian].

Supreme Court. (2018, September 20). Case on checking the procedure of applying tariffs for services in seaports. (No. 2a-12088/09/1570). https://zakononline.com.ua/court-decisions/show/76615227 [in Ukrainian].

Supreme Court. (2018, September 7). Case on establishing the lack of powers of the port authorities to set the rate of the tonnage dues for foreign-flagged vessels engaged in cabotage as for vessels engaged in international voyages. (No. 815/6436/15). https://protocol.ua/ru/postanova_kas_vp_vid_07_09_2018_ roku_u_spravi_815_6436_15/[in Ukrainian].

Supreme Court. (2021, April 1). Case on granting permission for the vessel to enter commercial seaport. (No. 814/1100/18). https://vkursi.pro/vsudi/ decision/95945796 [in Ukrainian].

Supreme Court. (2020, October 19). Case on pollution of inland sea waters and territorial sea of Ukraine due to discharge of ballast waters into the water area of the Adzhalyk Liman. (No. 420/4129/19). https://zakononline.com.ua/courtdecisions/show/92270250 [in Ukrainian].

Supreme Court. (2018, March 3). Case on recognition of illegal inaction of Harbormaster to issue a permit for the vessel to leave the seaport. (No. 815/2294/15). https://protocol.ua/ru/postanova_kas_vp_vid_14_03_2018_ roku_u_spravi_815_2294_15/[in Ukrainian].

Supreme Court. (2021, February 16). Case on the appeal of the refusal to agree on the research program concerning fishing in the five-kilometer coastal zone along the Ukrainian coast of the Azov Sea. (No. 808/2192/16). https://data-ua.com/doc/92060758/persons [in Ukrainian].

Supreme Court. (2021, September 16). Case on the recognition of illegal inaction of the State Ecological Inspection of Ukraine in not carrying out radiological control of the cargo, which led to the detention of the ship. (No. 815/658/18). [in Ukrainian].

Supreme Court. (2021, June 16). Case on the refusal of the vessel to leave the port due to the prohibition decision of the border service. (No. 2140/1776/18). http://iplex.com.ua/doc.php?regnum $=97806603 \&$ red $=10000317$ cd3806401f9d5c28308c68377 afb23\&d=5 [in Ukrainian]. 
Supreme Court. (2018, December 6). Case regarding non-compliance with conditions of storage of food products (fish) located in boxes on the berths in the port area. (No. 808/3534/13-a). https://zakononline.com.ua/courtdecisions/show/78391720 [in Ukrainian].

Сзеров А. Огляд позицій Верховного Суду Украйни по спорах у сфері морського права (адміністративна юрисдикція). - Стаття.

У цій статті наведено огляд правових позицій Верховного Суду України 3 морських спорів у рамках адміністративної юрисдикції. У цій категорії справ виникають спори щодо виконання чи невиконання функцій державного управління або про надання чи ненадання адміністративних послуг з питань, пов'язаних із судноплавством, рибальством, функціонуванням морських портів, охороною навколишнього середовища у прибережних водах тощо. У статті переважно розглядаються справи щодо заборони заходження суден до порту, послуг капітанів портів, забруднення прибережних вод та рибальства. Крім того, особлива увага приділяється спорам, пов'язаним з правовим режимом правозастосування у морських портах щодо здійснення функцій портової влади та інших органів, що мають право на різні види контролю у порту (зокрема, екологічний).

Ключові слова: морські спори, адміністративна юрисдикція, морські порти, капітани портів, портова влада, Україна.

Езеров А. Обзор позиций Верховного Суда Украины по спорам в сфере морского права (административная юрисдикция). - Статья.

В данной статье представлен обзор правовых позиций Верховного Суда Украины по морским спорам в рамках административной юрисдикции. В данной категории дел возникают споры о выполнении или невыполнении функций государственного управления либо об оказании или неоказании административных услуг по вопросам, связанным с судоходством, рыболовством, функционированием морских портов, охраной окружающей среды в прибрежных водах и т.п. В статье преимущественно рассматриваются дела, касающиеся запрета захода судов в порт, услуг капитанов порта, загрязнения прибрежных вод и рыболовства. Кроме того, особое внимание уделяется спорам, связанным с правовым режимом правоприменения в морских портах в части осуществления функций портовых властей и иных органов, имеющих право на различные виды контроля в порту (в частности, экологический).

Ключевые слова: морские споры, административная юрисдикция, морские порты, капитаны портов, портовые власти, Украина. 